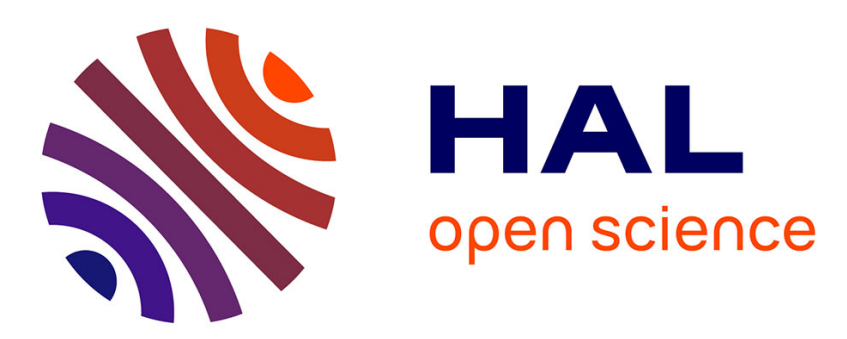

\title{
DEPENDENCE OF CONVOY ELECTRON EMISSION ON SURFACE PROPERTIES AND TARGET MATERIAL
}

H. Rothard, M. Burkhard, C. Biedermann, J. Kemmler, K. Kroneberger, P. Koschar, O. Heil, D. Hofmann, K. Groeneveld

\section{To cite this version:}

H. Rothard, M. Burkhard, C. Biedermann, J. Kemmler, K. Kroneberger, et al.. DEPENDENCE OF CONVOY ELECTRON EMISSION ON SURFACE PROPERTIES AND TARGET MATERIAL. Journal de Physique Colloques, 1987, 48 (C9), pp.C9-215-C9-218. 10.1051/jphyscol:1987933 . jpa00227351

\section{HAL Id: jpa-00227351 https://hal.science/jpa-00227351}

Submitted on 1 Jan 1987

HAL is a multi-disciplinary open access archive for the deposit and dissemination of scientific research documents, whether they are published or not. The documents may come from teaching and research institutions in France or abroad, or from public or private research centers.
L'archive ouverte pluridisciplinaire HAL, est destinée au dépôt et à la diffusion de documents scientifiques de niveau recherche, publiés ou non, émanant des établissements d'enseignement et de recherche français ou étrangers, des laboratoires publics ou privés. 


\title{
DEPENDENCE OF CONVOY ELECTRON EMISSION ON SURFACE PROPERTIES AND TARGET MATERIAL ( 1 )
}

\author{
H. ROTHARD, M. BURKHARD, C. BIEDERMANN, J. KEMMLER, \\ K. KRONEBERGER, P. KOSCHAR, O. HEIL, D. HOFMANN and \\ K.O. GROENEVELD \\ Institut für Kernphysik der Joh. Wolfg. Goethe-Universität, \\ August-Euler-Strasse 6, D-6000 Frankfurt-am-Main 90, F.R.G.
}

\section{Rěsumé}

L'influence de la surface d'un solide sur l'emission des électrons "convoyés" a été étudiée pour différentes cibles solides (C,Al,Ni,Cu, $\mathrm{Pd}, \mathrm{Ag}, \mathrm{Sm}, \mathrm{Gd}, \mathrm{Au}$ et $\mathrm{Bi})$ avec des surfaces propres, bombardées avec des projectiles atomiques et moléculaires légers $\left(\mathrm{H}^{+}, \mathrm{H}_{2}{ }^{+}\right)$et des ions lourds $\left(\mathrm{Kr}^{+}\right)$dans l'ultra vide $\left(\mathrm{p}=10^{-7} \mathrm{~Pa}\right)$. Le rendement des électrons convoyés dépend fortement des impurités adsorbées. Pour la première fois, la dépendence de l'émission des électrons convoyés en fonction du materiau de la cible a été étudiée systématiquement.

\section{Abstract}

The influence of surface properties on the convoy electron emission from sputter-cleaned solid surfaces (C,Al, $\mathrm{Ni}, \mathrm{Cu}, \mathrm{Pd}, \mathrm{Ag}, \mathrm{Sm}, \mathrm{Gd}, \mathrm{Au}$ and $\mathrm{Bi}$ ) induced by both light ions $\left(\mathrm{H}^{+}, \mathrm{H}_{2}{ }^{+}\right)$and heavy ions $\left(\mathrm{Kr}^{+}\right)$has been studied under ultrahigh vacuum conditions $\left(p=10^{-7} \mathrm{~Pa}\right)$. The convoy electron yield depends strongly on the surface coverage with adsorbed substances. First systematic studies of the dependence of the convoy electron yield on the target material are presented.

Since the discovery of convoy electrons in $1970 / 1 /$, many experiments concerning the dependence of convoy electron emission on e.g. the initial charge state of the projectile, the charge state of the emerging ion and the target thickness have been performed $/ 2,3 /$. All these measurements were carried out under standard high vacuum conditions $\left(\mathrm{p}=10^{-5} \mathrm{~Pa}\right)$ (most of them with carbon targets), so that no information on the dependence of convoy electron emission on both surface composition and structure has been obtained. Because of uncontrolied surface conditions, until now no systematic studies of the dependence of convoy electron emission on the target material could be realized. In this paper, we present the first data of convoy electron yields from controlled solid surfaces.

Both the total secondary electron yield and the shape of ion induced

\footnotetext{
(1) Supported by Bundesministerium für Forschung und Technologie BMFT Bonn, under contract number of of $173 / 2$ Ti 476
} 


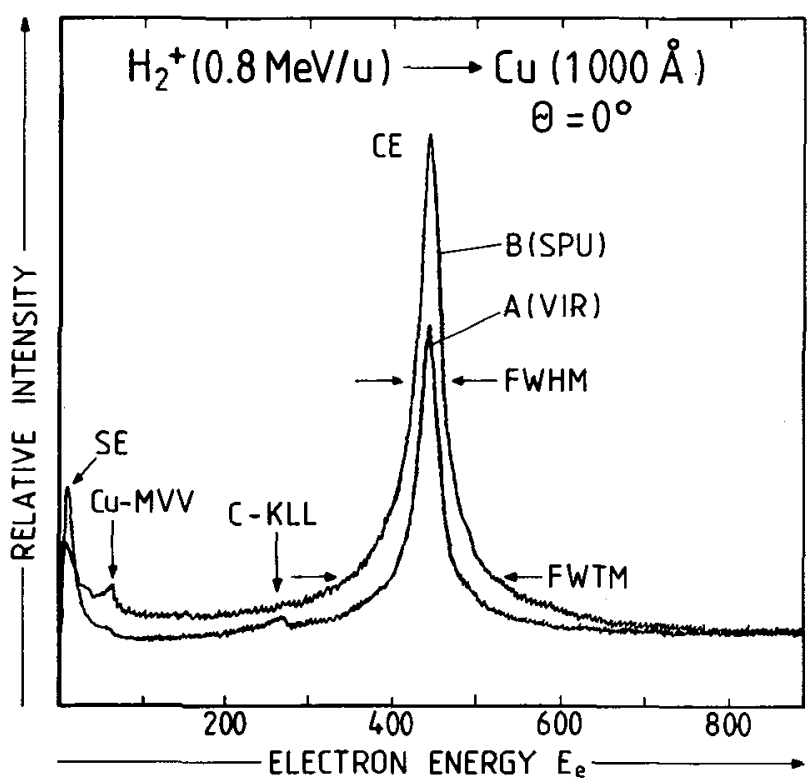

Fig.1: Electron energy spectra from uncleaned (A) and sputter-cleaned (B) copper surfaces induced by $\mathrm{H}_{2}{ }^{+}$-ions $(0.8 \mathrm{MeV} / \mathrm{u})$.

secondary electron spectra depend on the coverage of the surface with adsorbed substances $/ 4,5 /$. This is shown in fig. 1 , which presents electron energy spectra (observation angle $\theta=0^{\circ}$, from an uncleaned ("virginal", A) and a sputter-cleaned (B) copper target $(\mathrm{d}=1000 \quad A$ ) bombarded with $\mathrm{H}_{2}{ }^{+}$-ions $(0.8 \mathrm{MeV} / \mathrm{u})$. The target was sputtered with $\mathrm{Kr}^{+}$-ions $\left(24 \mathrm{keV} / \mathrm{u} ; 18 \mathrm{nA} \mathrm{min} / \mathrm{mm}^{2}\right)$. The surface was controlled by means of Auger electron spectroscopy (AES), secondary electron spectroscopy (SES) and Rutherford forward scattering (RFS) $16,7 /$. In spectrum $A$, one sees 1 . the "true" secondary electron peak at energies $\mathrm{E}_{\mathrm{e}}<10 \mathrm{eV}$ (SE), 2. the carbon KLL Auger electron distribution around $E_{e}=268$ eV resulting from carbon adsorbed at the copper surface and 3 . the convoy electron peak at $E_{e}=440 \mathrm{eV}(C E)$. All these structures change drastically after the surface has been cleaned: 1 . The "true" secondary electron peak diminishes because the work function of a clean metal surface is higher than that of a surface covered with adsorbates. This leads to a reduced probability for low energy electrons to be transmitted through the surface potential barrier. The high energy delta electrons are not affected by the surface potential, therefore in the high energy region $E_{e}>600 \mathrm{eV}$ the spectra $A$ and $B$ are equal. 2. As the surface is cleaned from carbon adsorbates, no more carbon KLL Auger electrons appear in spectrum B, whereas the copper 


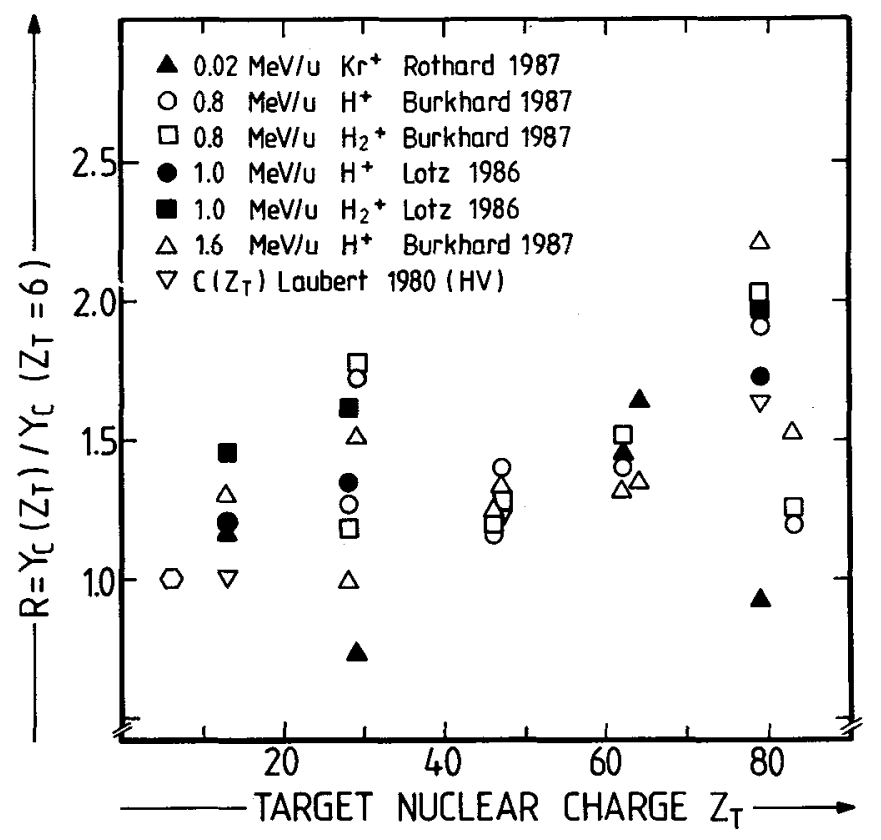

Fig.2: Compilation of available data on the dependence of the convoy electron yield (normalized to carbon) on the target material (from refs. $(7,8,10,11 /)$, see text (Typical error bar $+/-10 \%$ ).

MMV Auger electrons at $\mathrm{E}_{e}=63 \mathrm{eV}$ from the clean copper surface can be observed. 3. Surprisingly, both the total convoy electron yield and the peak shape show a significant change: The convoy electron yield $\mathrm{Y}_{C}$ is enhanced by a factor of $2.35\left(Y_{C}(B)=2.35 Y_{C}(A)\right)$ and the full width at half maximum (FWHM) and the full width at tenth maximum (FWTM) are enhanced, too (after subtraction of the ionisation electron background). This indicates that the origin of these convoy electrons is to a rather large fraction in the last few atomic layers of the solid.

Only few measurements had been made concerning the dependence of the convoy yield on the target material $/ 8,7 \%$. In these experiments, only a few target materials had been used. The convoy electron yield $\mathrm{Y}_{\mathrm{C}}$ as a function of the target atomic number $\mathrm{z}_{\mathrm{T}}$, the projectile atomic number $\mathrm{z}_{\mathrm{P}}$ and the projectile energy $\mathrm{E}_{\mathrm{P}}$ was found to obey the empirical equation $Y_{C}=10^{-4} c\left(z_{T}\right) \quad z_{P}^{m} E_{P}{ }^{-n}$ with $m=2.75 \pm 0.2, \quad n=2.25 \pm 0.1$ and a constant $c\left(z_{T}\right)$ depending on the target material. The values for $c\left(z_{T}\right)$ from refs. $/ 7,8 /$ are shown in fig. 2. Additionally, in fig. 2 we present convoy electron yields normalized to that of carbon $\left(R=C=Y_{C}\left(Z_{T}\right) / Y_{C}\left(Z_{T}=6\right)\right)$ from many different target materials (C,AL,Ni, $\mathrm{Cu}, \mathrm{Pd}, \mathrm{Ag}, \mathrm{Sm}, \mathrm{Gd}, \mathrm{Au}$ and $\mathrm{Bi})$ with cleaned surfaces bombarded with $\mathrm{H}^{+}(0.8$ 
$\mathrm{MeV} / \mathrm{u}, 1.6 \mathrm{MeV} / \mathrm{u}), \mathrm{H}_{2}{ }^{+}(0.8 \mathrm{MeV} / \mathrm{u})$ and $\mathrm{Kr}^{+}(0.02 \mathrm{MeV} / \mathrm{u})$. No "simple" dependence on the target nuclear charge (like e.g. ${ }^{2}{ }^{n}$ ) as predicted by conventional ionisation theories $/ 2 /$ can be seen. Furthermore, even in the case of neighbouring elements (e.g. $\mathrm{Ni}$ and $\mathrm{Cu}$ or $\mathrm{Pd}$ and $\mathrm{Ag}$ ), extremly different convoy electron yields are observed. This is a clear hint for a solid state effect in the sense that either the production of convoy electrons or their transport to the surface according to the model of ref. /9/ are affected by the properties of the solid. In the case of low energy convoy electrons, the convoy electron yield shows a clear dependence on the workfunction: It decreases with increasing workfunction, so that the surface potential seems to affect low energy convoy electron emission $/ 10 /$. In the case of light ions, the convoy electron yield shows a dependence on the Fermi energy $E_{F}$, i.e. the valence electron density $n_{e}$ of the studied materials $/ 11 \%$. This could be due to transport properties in the solid. According to ref. 19/, the equilibrium value of th $\mathrm{CE}$ Yield $\mathrm{Y}_{\mathrm{C}}$ is a function of a transport length $\lambda_{C}$, which is comparabel to the inelastic mean free path $\lambda_{e}$ of free electrons, and the electron capture cross section $\sigma_{C}\left(Y_{C} \sim \lambda_{C} \cdot \alpha_{C}\right)$, but actually no clear dependence of the convoy electron yield on the attenuation length for electron transport $/ 12 /$ can be stated. Another possibility is that a large part of the convoy electrons result from the capture of electrons from the valence band depending on the electron density.

/1/ K.G.Harrison and M.W.Lucas, Phys. Lett. 33A (1970) 142

$12 /$ "Forward Electron Ejection in Ion Collisions" K.O.Groeneveld, W.Meckbach and I.A.Sellin, editors Springer, Heidelberg, LNP213 (1984)

/3/ J.Kemmler èt al.; Debrecen

/4/ D.Hasselkamp,S.Hippler and A.Scharmann Nucl. Instr. Meth. B18 (1987) 561 (and references therein)

/5/ M.Burkhard,H.Rothard,C.Biedermann, J.Kemmler, P.Koschar and K.o.Groeneveld, Nucl. Instr. Meth. B24/25 (1987) 143

/6/ M.Burkhard,H.Rothard,J.Kemmler,K.Kroneberger and K.O.Groeneveld accepted by J. Phys. D

/7/ W.Lotz,M.Burkhard, P.Koschar,J.Kemmler,H.Rothard, C.Biedermann, D.Hofmann and K.O.Groeneveld, Nucl. Instr. Meth. A245 (1986) 560

18/ R.Laubert, I.A.Sellin, C.R.Vane,M.Suter, S.B.Elston, G.D.Alton and R.S. Thoe, Nucl. Instr. Meth. 170 (1980) 557

$19 /$ P.Koschar,A.Clouvas, O.Heil,M.Burkhard,J.Kemmler and K.O.Groeneveld, Nucl. Instr. Meth B24/25 (1987) 153

$/ 10 /$ H.Rothard,M.Burkhard, C.Biedermann, J.Kemmler, P.Koschar, K.Kroneberger, O.Heil, D.Hofmann and K.O.Groeneveld Preprint (1987)

/11/ M.Burkhard, Thesis, J.W.Goethe-Univ., Frankfurt, Germany (1986), and M.Burkhard et al., to be published

112 / C.J.Powell, Scanning Electron Microscopy IV (1984) 1649 